\title{
LMS Technical Analysis: problems of choice
}

\author{
Egor Mishchenko, ${ }^{1 *}$ \\ ${ }^{1}$ Saint Petersburg National Research University of Information Technologies, Mechanics and Optics \\ University ITMO, St. Petersburg, Russia
}

\begin{abstract}
The Learning Management System (LMS) has been created at a number of universities around the world to help bring students and faculty together without the constraints of a traditional classroom. This study explained the selection issues, explained the differences between LMS and LCMS, and highlighted the selection criteria. The result of the article is an analysis of popular CMS by the selected criteria
\end{abstract}

\section{Introduction}

In the beginning of this century IT significantly changed the society in all common aspects of life. Companies from various domains started trying to take advantage from new technologies in software and hardware. It happens from oil \& gas industry up to the agricultural sector, it's obvious that it's impossible to name a single sphere that wasn't impacted by IT boom. What is even more important, the IT development greatly changed the education in schools and Higher Education Organizations (HEOs).

The COVID-19 greatly changed people's common lifestyle. Nowadays lockdown is a common buzzword that has become popular during corona pandemic. In fact, lockdown is a state of the emergency protocol implemented by the competent authorities to restrict people from leaving their homes. Schools across the globe have closed down temporarily to protect students, teachers, and staff from possible infection. In fact, a study by UNESCO says that almost 1.2 billion of students in 143 countries are affected by the pandemic [1]. This forced people to start looking for ways to transfer learning to a distance format. Most higher education institutions were not ready for this, did not have the capacity and experience in the field of distance learning. Schools, colleges and versatile waste from the four walls of their classrooms and take advantage of the digital space. A recent study shows that educational institutions are poised to invest up to $\$ 350$ billion in educational technology by 2025 . This includes tools such as video conferencing, virtual learning, and most importantly, Learning Management Systems (LMS).

LMS are software solutions that manage the administration, monitoring and reporting of online courses and curricula within an organization. It serves as a virtual classroom where teachers can interact with their students and conduct learning activities online. The virus is not a death sentence to education. With the right tools like the LMS, COVID-19 is paving the way for a different form of learning and teaching. Teachers can continue their work to educate the younger generation, and students will not be bored with sitting at home. After all, films can give that kind of sense of normality during these difficult times. Thus, LMS is

* Corresponding author: vicpost@inbox.ru 
very important, especially now, when COVID-19 continues to pose a threat to the health and safety of everyone. This will ensure the continuity of education as well as ensure the effectiveness of online learning [2].

All those factors forced HEO completely changed its position on the use of technologies and equipment available to the masses of users through ICTs, and here we should mention the boom recorded by the development of mobile devices. Based on developments in the field of ICT, as well as on the broad and easy access to these developments, the HEO was given the time and opportunity to look for various solutions for learning management, paying more attention to the use of LMS in their educational programs. There is still no detailed LMS overview on the types of LMS that are available, on the challenges of choosing anf implementing LMS, etc. It is enough to consider a simple answer to the possible question of why a HEO should use LMS at all, and an answer that is given in the same simplicity by the ultimate goal of any HEO, that is, achieving customer satisfaction [3]. Considering as the main client of the student, the ultimate goal will be a successful student, who nevertheless, is a student that not only graduated from the faculty, but can be immediately hired with an employment package, is considered satisfactory for the junior class.

Whether it's distance learning or traditional learning, the evidence shows that both require careful planning. There are many pros and cons of distance learning. Some professors argue that distance learning is ideal for many students. A comparison of distance learning and traditional learning will show that both are good depending on who the student may be and what educational program they have chosen.

Indeed, among all the definitions given to LMS by various researchers and specialists in the domain, the one provided by Berking, \& Gallagher (2013) has been defining LMS as "anytime, anywhere" access to learning content and administration" [14]. According to the author, LMS can be defined as a set of software platforms delivered to users by instructors through the Internet and using various hardware, with the aim of delivery in the shortest possible time a high level of knowledge in the subject area, ensuring at the same time complete management of the entire educational cycle, including data and information. HEO have been involved in the use of proprietary LMS from the very beginning, and, in fact, HEO have played and are also currently playing a very important role from this point of view because of the fact that students are mostly teenagers between the ages of 18 and 29.

The quality of distance learning should take into account, in particular, the learning management system and its capabilities; technology used for instructional strategy; interactivity of students and teachers; subsidiary services and resources; learning assessment and financial viability of the training system (Sinclair 2003). The participation of other stakeholders in funding will support and facilitate the use of ICTs in educational environment (ILO 2005). Educational institutions should work closely with stakeholders to ensure providing high quality educational content; a variety of training activities and support services for teachers and students (UNESCO 2020).

\section{Materials and Methods}

The main criteria for choosing the means of organizing e-learning include the following:

- Functionality. Indicates the presence in the system of a set of functions at various levels, such as forums, chats, analysis of student activity, management of courses and trainees, as well as others;

- Reliability. This parameter characterizes the ease of administration and the ease of updating content based on existing templates. Convenience management and protection from external influences significantly affect the attitude of users to the system and the effectiveness of its use; 
- Stability. Indicates the degree of stability of the system in relation to different operating modes and the degree of user activity;

- Cost. It consists of the cost of the system itself, as well as the costs of its implementation, course development and maintenance, the presence or absence of restrictions on the number of licenses for students;

- Availability of content development tools. The built-in educational content editor not only facilitates the development of courses, but also allows you to integrate educational materials for various purposes in a single view;

- SCORM support. The SCORM standard is the international basis for the exchange of electronic courses and the lack of its support in the system reduces mobility and does not allow you to create portable courses;

- Knowledge verification system. Allows you to evaluate students ' knowledge online. Usually, such a system includes tests, tasks, and monitoring the activity of trainees on the forums;

- $\quad$ Ease of use. When choosing a new system, it is necessary to ensure the convenience of its use. This is an important parameter, because potential students will never use technology that seems cumbersome or makes it difficult to navigate. The learning technology should be intuitive. In the training course it should be easy to find the help menu, navigate from one section to another and communicate with the instructor.

- Modularity. In modern EO systems, a course can be a set of micromodules or blocks of learning material that can be used in other courses.

- Providing access. Trainees should not have obstacles to access to the curriculum due to their location in time and space, as well as possible factors that limit the capabilities of the trainees (limited body functions, impaired vision). Also, the use of "tomorrow" technologies, which are supported by a limited range of software, significantly reduces the number of potential users.

- $100 \%$ multimedia content. The ability to use as content not only text, hypertext and image files, but also audio, video, gif and flash animations, 3D graphics of various file formats.

- Scalability and extensibility. The possibility of expanding both the range of students trained in the LMS, and the addition of programs and courses of training and education.

- $\quad$ Prospects for the development of the platform. The LMS should be a developing environment, and new, improved versions of the system should be released with support for new technologies, standards, and tools.

- $\quad$ Cross-platform LMS. Ideally, a distance learning system should not be tied to any operating system or environment, either at the server level or at the client machine level. Users should use standard tools without downloading additional modules, programs, etc. [4]

The LMS is a high-level, strategic solution for planning, delivering and managing all educational activities in an organization, including online training, virtual classrooms, and instructor-led courses. The main challenge is to replace isolated and disparate training programs with systematic methods for assessing and improving competence and performance levels across the organization. For example, LMS greatly simplifies international certification, allows companies to align training initiatives with strategic objectives, and develop effective enterprise-wide knowledge management practices. The focus of LMS is to manage learners by tracking their progress and growth across all types of learning activities. It performs costly administrative tasks such as generating reports and data for HR and other ERP systems, but in most cases it is not used to create training courses.

In contrast, the main focus of Learning Content Management System (LCMS) is educational content. It provides authors, designers and experts with the means to create educational materials more efficiently. The main business challenge that LCMS solves is the creation of the required content in the required time to meet the needs of individual students 
or groups. Before designing the course itself and adapting it to a large audience, designers create reusable objects and provide them to all course developers in the organization. This eliminates duplication of developer efforts and allows you to quickly "collect" customized content.

IDC defines LCMS as a system that creates, stores, collects, and plays personalized learning content in the form of learning objects [7]. While LMS manages all forms of learning in an organization, LCMS concentrates on online learning content, usually in the form of learning objects.

A learning object is an isolated (closed) part of learning material. It usually consists of three components: an attainable goal (what learners should understand or achieve when they graduate), educational content required to achieve the goal (text, video, illustrations, structured slides, demonstrations, simulations) and various forms of assessment that allow to determine whether the goal has been achieved or not.

The learning object also includes metadata, or tags, that describe its content and use in the LCMS. Metadata can include information such as author, language, version level, and more. In Techniques, Metadata and E-Learning, the author, Dave Feezy of Eyepopping Design, predicts: who needs to be ready. " [8]

So how are learning objects used to create content? In LCMS, learning objects are stored in a central repository, so designers can take them and insert them into their personalized courses. This provides an advantage for developers and learners, as traditional courses are forced to contain more content than an individual learner can master, or needs to master to understand a topic. Dividing course content into learning objects and using them as a basis in the future allows developers to create the right courses at the right time. The end result is increased productivity because users do not need to spend unnecessary time "wading through deposits" of obsolete material.

\section{Results}

Over the past two years, a new class of Learning Content Management System (LCMS) has been developing. Unlike LMS, such systems focus on the tasks of managing the content of training programs, rather than the learning process, and are not aimed at managers and students, but at content developers, specialists in the methodological layout of courses and managers of training projects. LCMS is based on the concept of presenting learning content as a set of reusable learning objects with their target audience and a specific context of use. According to analysts, the boundary between the two classes of systems with such similar names is increasingly difficult to draw: most manufacturers of LCMS systems include the functionality of general learning management in them, and the leading solutions of the LMS category now implement the capabilities of managing educational content.

Despite many variations in the capabilities of the LCMS, it should include the following key components:

A repository of learning objects. A learning object repository is a central database that stores and manages learning content. From this point, individual learning objects are available to users either as individual elements or as part of a larger learning module, which in turn can be part of a full course; this process is determined depending on individual learning requirements. The final product can be accessed via the Web, CD-ROM, or in paper form. Each object, depending on the requirements, can be used several times and for different purposes. The content is integrated regardless of the delivery method. For individual elements, this is provided by the logic of the program code using XML.

Automated autoring software. This software is used to create reusable training objects, which will then be available in the repository. The app automates development by providing authors with templates and archived samples containing the basic design principles of 
educational content. Using these templates, authors can develop courses by applying existing objects from the repository, creating new objects, or using a combination of new and old objects. Authors can be experts on the subject, designers of training courses, creators of media products, leaders of communities of practice, and so on. This tool can also be used to quickly convert existing educational content libraries in the organization, such as additional audio-visual materials, special interfaces, and teaching methods. The author can work in an organization or outsource development.

Interface for displaying (playing content). To present training objects in accordance with the training profile, for preliminary testing, and/or in accordance with user requests, an interface for displaying materials is required. This component also provides tracking of results, links to relevant information sources, and various options for evaluation and feedback from users. This interface can be configured for a specific organization that uses LCMS. For example, content can be presented on web pages that contain the organization's logo and design elements adopted in the current corporate style. In addition, the controls and design elements can be localized to the desired region.

Administration tools. This application is used to manage student accounts, run courses from the catalog, track results, compile reports on the learning process, and other simple administrative functions. This information can be passed to an LMS designed to implement more advanced administrative functionality.

The shadow side of using LCMS is that it allows you to give a big boost to planning and obtaining design skills for effective training facilities because it provides templates and examples for use. Designers need to think non-linearly and have a good understanding of all the different content options for which the object will be needed or can be used. For example, if a learning object goes beyond the scope of the content or does not provide enough means of assistance, then it will bring harm rather than benefit. Some courses must contain a certain set of sections in a certain order and cannot be divided into separate parts.

The LCMS market is still quite fragmented, which indicates its immaturity, but it is developing rapidly; systems of this class are becoming more and more popular and are considered not just as a necessary infrastructure for eLearning, but — at least by Western companies - as part of the overall corporate IT infrastructure. This is confirmed by the interest shown in learning management solutions by manufacturers of general management systems, including SAP (SAP Learning Solution), Oracle (iLearning), and PeopleSoft (Enterprise Learning Management).

Learning Management Systems (LMS) and Learning Content Management Systems (LCMS) have different goals. The main task of the LMS is to automate the administrative aspects of training, and the LCMS focuses on managing the content of "training objects".

Both LMS and LCMS manage course content and track learning outcomes. Both tools can manage and track content, all the way down to the training facility level. But the LMS, at the same time, can manage and track blended learning made up of online content, classroom activities, virtual classroom meetings, and other various sources. In contrast, LCMS cannot manage blended learning, but can manage content at the granulation level below the training facility, allowing the organization to more easily restructure and re-target online content. Additionally, advanced LCMS are able to dynamically build learning objects according to user profiles or learning styles. If both systems adhere to XML standards, the information can simply be moved to the LMS at the training object level. 
Table 1. Summarizes the capabilities and differences between the two LMS and LCMS systems.

\begin{tabular}{|l|c|c|}
\hline & LMS & \multicolumn{2}{|c|}{ LCMS } \\
\hline For whom is it intended? & All students; organization & $\begin{array}{l}\text { Content Developers; } \\
\text { Students who need } \\
\text { personalized content }\end{array}$ \\
\hline Basically provides management & $\begin{array}{l}\text { Learning process; learning } \\
\text { requirements; training } \\
\text { programs and planning }\end{array}$ & Educational content \\
\hline Manages e-learning & Yes & Yes \\
\hline $\begin{array}{l}\text { Manages traditional forms of } \\
\text { learning }\end{array}$ & Yes & No \\
\hline Tracks the results & Yes & Yes \\
\hline Supports student collaboration & Yes & No \\
\hline $\begin{array}{l}\text { Enables HR and ERP systems to } \\
\text { use training data }\end{array}$ & Yes & Yes \\
\hline $\begin{array}{l}\text { Analysis of competence } \\
\text { profiles/knowledge maps }\end{array}$ & Yes & Yes \\
\hline $\begin{array}{l}\text { Creating and Management of } \\
\text { tests }\end{array}$ & Yes & Yes \\
\hline Support for content creation & Yes \\
\hline Organizing reusable content & & Yes \\
\hline $\begin{array}{l}\text { Workflow tools for managing } \\
\text { the content creation process }\end{array}$ & & \\
\hline
\end{tabular}

Although some LMS have proprietary applications and content management capabilities, and LCMS offer minimal LMS features, attempts to use the same system to perform both tasks may not always be optimal. Since LCMS focus on authoring tasks and content delivery, their tools for solving these tasks are more developed than those available in the LMS. On the other hand, the LMS offers a large number of features that are important for course administrators with a large number of students than the basic features that are available in the LCMS.

The problem of choosing the platform on which the virtual learning environment will be built is key, and this choice depends on a number of factors: what requirements are imposed on the environment, what functional characteristics should be present, for which users the environment is aimed and, importantly, what means you should purchase and maintain the necessary platform.

The advantages of commercial software are widely known: most of them are reliable products (especially those that have proved themselves in the market), with an appropriate level of user support, regular updates and new versions.

However, there are drawbacks. Thus, for example, there is a problem of "closed doors" when using LMS on closed platforms. First, the source code is not available to the organization's technical support, so even small changes at the user level are not possible. The organization may try to contact the manufacturer if they have suggestions for improvement, but it is very unlikely that their ideas will be implemented in a short period of time, if at all. In addition, the disadvantages include the high cost of any commercial product, regular payments for a license, an increase in the number of users (which is generally the goal of any network community), and so on.

Another way is to implement LMS based on open source solutions. The undoubted advantage of the product is that the OS is the most natural choice for educational projects, since its roots lie in the idea of cooperation, and the ideology itself allows you to combine the talents and experience of a large number of teachers and students, and programmersvolunteers in the development and improvement of educational software products. Moreover, such learning software can function as a student-centered tool, as a framework for flexible, 
adaptable learning tailored to a specific curriculum. The most common way to purchase a DMS is to purchase a ready-made solution with documented capabilities, on the basis of which the customer organization solves the task of deploying distance learning. The cost of the software usually includes detailed documentation, methodological and technical support. At the same time, the customer organization independently puts the system into operation.

The commissioning of the LMS by the developer is carried out within the framework of the implementation project, which is much more expensive and, as a result, less common among Russian organizations. Nevertheless, upon completion of the project, the customer company receives a unique system that can solve almost all the tasks set.

The least risky scheme from the point of view of financial costs is the use of an ASP service. The essence of the service boils down to the fact that the user gets access to an existing functional LMS, created on the basis of a particular product.

The fourth way is the deployment of a freely distributed LMS by the organization. This way allows you to significantly reduce the cost of implementing the project of deploying the LMS, "sharpen" the system to your needs and requirements, but almost the entire burden of implementing the system falls on the IT service of the organization. The implementation project may take a long time, due to the lack of operational technical support from the Open Source community.

Table 2. The result of the study is a summary table comparing popular LMS by the criteria defined above, which will help in choosing a solution.

\begin{tabular}{|c|c|c|c|c|c|}
\hline Criteria & Moodle & openEdx & Canvas & Docebo & iSpring Learn \\
\hline Functionality & \multicolumn{4}{|c|}{$\begin{array}{l}\text { It is possible to develop your own modules that allow } \\
\text { you to expand the capabilities of the system } \\
\text { indefinitely }\end{array}$} & $\begin{array}{l}\text { There is no scope for } \\
\text { development, but } \\
\text { there are many } \\
\text { developed modules } \\
\text { available for use. }\end{array}$ \\
\hline Reliability & High & High & High & High & High \\
\hline Stability & High & High & High & High & High \\
\hline Cost & $\begin{array}{l}\text { Open } \\
\text { Source }\end{array}$ & Open Source & $\begin{array}{l}\text { Open } \\
\text { Source, }\end{array}$ & $\begin{array}{l}1600 \$ \\
\text { per } \\
\text { month }\end{array}$ & $4 \$$ per user \\
\hline $\begin{array}{l}\text { Availability of } \\
\text { content } \\
\text { development } \\
\text { tools. }\end{array}$ & + & + & + & + & - \\
\hline $\begin{array}{l}\text { SCORM } \\
\text { support }\end{array}$ & + & + & + & + & + \\
\hline Ease of use. & + & + & + & + & + \\
\hline Modularity & + & + & + & + & $+/-$ \\
\hline $\begin{array}{l}\text { Providing } \\
\text { access }\end{array}$ & + & + & + & + & + \\
\hline $\begin{array}{l}\text { Multimedia } \\
\text { content }\end{array}$ & + & + & + & + & + \\
\hline $\begin{array}{l}\text { Scalability and } \\
\text { extensibility }\end{array}$ & - & + & + & + & - \\
\hline $\begin{array}{l}\text { Prospects for the } \\
\text { development of } \\
\text { the platform }\end{array}$ & + & + & + & + & - \\
\hline $\begin{array}{l}\text { Cross-platform } \\
\text { LMS }\end{array}$ & + & + & + & + & + \\
\hline
\end{tabular}




\section{Conclusions}

Choosing an LMS is quite a voluminous task right now. On the one hand, there are commercial all-in-box solutions. Their advantages include ease of deployment for organizations, technical support, a set of ready-made high-quality modules, and guaranteed high quality. The disadvantages include a fairly high cost for educational institutions, the inability to customize. Free open source solutions also have a fairly large number of disadvantages: lack of technical support, low quality of products, but all these disadvantages are covered by the free product. There is also a fairly large community around the open source LMS. This community develops new models, helps to solve problems that arise during the operation of the LMS. Often, open source modules are not inferior in quality to a commercial product.

Proprietary LMS require licensing fees per user (15 to 100), usually on an annual basis, with additional subscription and service charges to ensure your system is kept up to date condition. LMS based on an open source software server like Moodle does not require a license fee, reducing the total cost per user [12].

Also, the open source software is free, and any new functionality is not worth implementing when upgrading (except perhaps a little thought about how to use the new features best). The proprietary software license cost is for each free update, so be careful to find out what exactly the license fee covers if you research proprietary systems.

If your organization decided to adopt Moodle today, the software itself would be worthless. You will have to purchase servers to host it and hire or train people to run the servers and optimize the software to run efficiently in your environment.

Do this for less than $\$ 20,000-30,000$ per year for a hosted LMS, then it may be better for you to bring the LMS into your home. Most companies use these numbers and decide to switch to an outsourcing model. Hosting outsourcing saves money and allows your organization to benefit from experts familiar with the management of Moodle LMS.

Assessing whether a proprietary or open source system is best for you should go beyond cost. If you take into account the risk associated with the potential destruction of a proprietary product through a merger or crash, an open source system provides a lower option since the source code "belongs" to everyone. Plus, thousands of developers should also be taken into account.

Developers of proprietary systems will argue that their LMS is easier to use than open source LMSs. This may have been true in the past, but today Moodle 2.6 and OpenEdx [13] perform simple functions that proprietary systems developed. In addition, open source systems are developed by the community as a whole. As a result, the number of features available as plugins provides an amazing array of options.

Finally, if you were an online training consultant, what would you rather specialize in? The most popular movie on earth, with over 60 million users? Or a small, proprietary system with thousands of clients? Many online training consultants support Moodle (or Totara for those in a corporate environment) over other systems to convey benefits to clients. As a result, the collective level of knowledge regarding optimization and the use of Moodle as a learning tool is enormous compared to other systems.

To summarize:

- Open source systems allow you to solve the same tasks as commercial systems, but at the same time users have the opportunity to refine and adapt a specific system to their needs and the current educational situation.

- Most open source systems are cross-platform solutions and are not tied to specific operating systems or specific Web browsers. 
- The use of commercial SDS is not available to most universities due to their high cost, the need to renew the license for each academic year, the binding of the cost of licenses and their renewal to the number of users of the system.

- Current trends in the development of Open Source LMS $\backslash$ LCMS are aimed at universalization and increasing the functionality of systems. In terms of their capabilities, the most advanced systems are not inferior to their commercial counterparts, and some even surpass them.

- Open source LMS allow you to implement the same set of functionality as commercial solutions with significantly lower economic costs.

- An analysis of the Internet information resources and reviews on forums on LMS issues showed that Moodle is of the greatest interest among Open Source systems. A distinctive feature of the Moodle project is that it has formed the most active international network community of developers and users who share their experience on the platform, discuss problems that have arisen, and exchange plans and results for further development of the environment.

\section{References}

1. A.V. Lyamin, M.S. Chezhin, S.N. Dekhnich, Scientific and technical bulletin of information technologies, mechanics and optics 15, 376 https://cyberleninka.ru/article/n/tipovaya-struktura-sistemy-distantsionnogoobucheniya

2. O.V. Rogozin, New information technologies in automated systems 5, 14-17 (2005) https://cyberleninka.ru/article/n/osnovnye-printsipy-organizatsii-modeley-scorm-vsistemah-elektronnogo-obucheniya

3. L.V. Sardak, L.N. Starkova, Pedagogical education in Russia 9, 120-127 (2014) https://cyberleninka.ru/article/n/postroenie-modulnoy-sistemy-upravleniyaobucheniem-v-vysshey-shkole-sredstvami-oblachnyh-servisov

4. V.N. Vasiliev, A.V. Lyamin, M.S. Chezhin, Scientific and technical bulletin of information technologies, mechanics and optics $5, \quad 31-50 \quad$ (2007) https://cyberleninka.ru/article/n/sistema-distantsionnogo-obucheniya-vtorogopokoleniya

5. A.S. Dorofeev, S.S. Sosinskaya, Applied Informatics 3, 15-25 (2007) https://cyberleninka.ru/article/n/modeli-obuchayuschego-kursa-v-razrabotke-sistemdistantsionnogo

6. O.A. Klyueva, Software products and systems 2, 31-58 https://cyberleninka.ru/article/n/obzor-perspektivnyh-napravleniy-razvitiyaelektronnogo-obucheniya-v-sistemah-obucheniya-operatorov-i-obrazovatelnyhkosmotsentrah

7. LCMS overview, https://idc.com/articles/406

8. D. Feezy, LMS technologies 1(274), 104-108 (2016) http://www.distancelearning.ru/db/el/B254358DE85FFE70C325723B0032F739/doc.html

9. Openedx https://openedx.atlassian.net/wiki/spaces/PLAT/pages/33358554/XBlocks/

10. Libnews, https://iblnews.org/labxchange-provides-an-overview-of-the-features-of-itsopen-edx-based-science-platform/

11. Opensource, https://opensource.com/article/19/1/openedx-openstack-complexlearning-environments 
12. Extension Blog, https://blog.extensionengine.com/what-is-a-xblock/

13. Open edX XBlock Tutorial, https://edx.readthedocs.io/

14. P. Berking, S. Gallagher, Advanced Distributed Learning (ADL) Initiative (2016) http://creativecommons.org/licenses/by-nc-sa/4.0/ 